\title{
LOOKING BACK AT ACCIDENT COMPENSATION: AN AUSTRALIAN PERSPECTIVE
}

Harold Luntz*

Soon after ACC was enacted the momentum for comprehensive no-fault reform shifted to Australia, where another Commission led by Sir Owen Woodhouse extended the New Zealand principles to address all forms of incapacity, including sickness, in an integrated scheme. The proposed Australian ACC model suggests the radical potential contained in the original Woodhouse vision, even though political events in Australia followed a different course from those in New Zealand. This paper explains the evolution of the Woodhouse principles in the context of Australian policy and politics, and offers reasons why the proposed scheme never came to enactment.

\section{INTRODUCTION}

It is sometimes said that in 1975 Australia came within a whisker of adopting a scheme of accident compensation similar to that which has been in operation in New Zealand since 1974. That is an exaggeration. There were indeed proposals at that time that would have led to an even more ambitious scheme for compensating people suffering from incapacity however caused. But the potential was there for many a slip between cup and lip and one such slip did occur. Even if it had not, there were others in waiting.

The purpose of this paper is to consider the events leading up to the Australian proposals, to outline briefly how the proposals differed from the scheme implemented in New Zealand and to recount what has happened in relation to the basic idea of no-fault compensation since that time. It is a matter of profound regret that the opportunity was lost to bring about radical change in the arrangements for compensating the incapacitated in Australia. Subsequent changes in economic and cultural attitudes have made a similar opportunity less likely in the near future. But the basic soundness of the five principles on which the New Zealand scheme was built - community responsibility, comprehensive entitlement, complete rehabilitation, real compensation and administrative efficiency - must surely lead to sense prevailing at some time in the future.

* George Paton Professor of Law, The University of Melbourne. 


\section{THE WHITLAM GOVERNMENT}

On 2 December 1972 a general election was held in Australia. It was clear on the night of the election that the Australian Labor Party (ALP) had obtained a majority of seats in the House of Representatives, the lower house of the Commonwealth Parliament. For the first time in 23 years, it would form a government. However, not all the members of the party who would win seats were immediately known. Australia's preferential voting system of single transferable votes sometimes requires the distribution of preferences to await the arrival of all postal votes and those cast by voters away from home. The outcome in individual constituencies often remains uncertain until this occurs. After the 1972 election, it was not possible to assemble the caucus, whose function it was under ALP rules to elect the members who would serve as ministers, for at least two weeks. That would bring the date for ministers to take up their portfolios close to Christmas, when everything tended to shut down.

The government was led by Mr E G (Gough) Whitlam, who had been preparing assiduously for his role. The spirit of the government was one of reform. Whitlam was impatient to implement the changes he had promised in his policy speech after so many years of conservative rule. He was not prepared to wait. He and his deputy, Mr Lance Barnard, were immediately allocated all 27 ministerial portfolios between them. They acted at phrenetic pace. The conscription of young men for service in the war in Vietnam was immediately terminated and draft resisters serving terms of imprisonment released. Whatever else could be done administratively to implement the Labor Party platform was put in train. ${ }^{1}$

\section{A Whitlam's Own Interest in Accident Compensation}

Whitlam was a man of many interests. One of his long-standing concerns was the need for the replacement of the fault system in the payment of compensation for injury. He records that "[f]or 23 years - from 1954 to 1977 - I campaigned against the great inefficiencies and inequities of the existing system". ${ }^{2}$ He first raised it at a caucus meeting prior to the 1954 election. $^{3}$ His initial proposals seem mainly to have been directed towards motor accidents. In a speech in Parliament on the subject on 29 September 1959, he referred to litigation arising out of such accidents as "the most prevalent and the least appropriate form of litigation in Australia ....". 4

1 A list of the decisions taken in the first two weeks of the government, as recorded by the Sydney Morning Herald, may be found in Whitlam's memoir, E Gough Whitlam The Whitlam Government 1972-1975 (Penguin, Melbourne, 1985) 19-22 (Whitlam memoir).

2 Whitlam memoir, above, 635.

3 Whitlam memoir, above, 635-636.

4 E Gough Whitlam (29 September 1959) 24 Parliamentary Debates (HR) 1485 (Australia). 


\section{B Whitlam's Proposed Replacement}

In that 1959 speech in Parliament, Whitlam said: ${ }^{5}$

The Commonwealth should, through the Department of Social Services, make periodic payments available to the victims of road accidents or their dependants to give them the same income after the accidents, until the age at which they retire or would have retired as they would have received but for the accident.

Shortly beforehand, he had intervened in a conference debate on a proposed Federal court for Australia, during which he stated: ${ }^{6}$

The victims of road accidents might be more justly and promptly compensated during their incapacity or bereavement if the Commonwealth Department of Social Services made periodical payments equivalent to their prior earnings, irrespective of negligence.

In January 1970, during a holiday cruise, Whitlam met Owen Woodhouse in Auckland. ${ }^{7} \mathrm{He}$ seems then to have been converted to the broader vision of a comprehensive national compensation scheme for accidental injuries. In a speech to an ALP seminar in 1971, he pointed to North American no-fault models of motor accident plans. In his conclusion, however, he referred to New Zealand being about to "enjoy", as a result of the Woodhouse report, "comprehensive 'no fault' protection against the consequences of accidents of every kind". ${ }^{8}$ He claimed that the party's platform contained a similar proposal. His policy speech for the 1972 election went even further. It promised that, on election, the ALP would establish a National Compensation scheme, which would "reduce hardships imposed by one of the great factors for inequality in society - inequality of luck". ${ }^{9}$

\section{ESTABLISHMENT OF WOODHOUSE COMMITTEE}

One of Whitlam's first acts on becoming Prime Minister was to phone New Zealand's then Prime Minister, Mr Norman Kirk. ${ }^{10}$ He asked that Mr Justice Woodhouse be released from judicial duties to head a committee of inquiry into an appropriate scheme for Australia. ${ }^{11}$ Very soon into his term

5 Parliamentary Debates, above, 1486.

6 E Gough Whitlam (1959) 33 ALJ 124.

7 E Gough Whitlam The Whitlam Government 1972-1975 (Penguin Books, Melbourne, 1985) 636 (Whitlam memoir); Geoffrey Palmer Compensation for Incapacity: A Study of Law and Social Change in New Zealand and Australia (Oxford University Press, Wellington, 1979) 133.

8 E Gough Whitlam "Traffic Injury Compensation" (ALP Seminar on Traffic Collisions, Terrigal (NSW), 31 October 1971).

9 Whitlam memoir, above, 637; Palmer, above, 133.

10 Whitlam memoir, above, 636.

11 Whitlam memoir, above. See also Palmer, above, 133. 
of office, in January 1973, Whitlam visited New Zealand. He took the opportunity to talk to Woodhouse about the terms of reference of the proposed inquiry. ${ }^{12}$ The following month, Woodhouse visited Australia and met his future colleagues on the inquiry. ${ }^{13}$ Whitlam announced the appointment of the members of the inquiry and the terms of reference in Parliament on 8 March 1973. ${ }^{14}$ Initially, there were three members. Woodhouse J chaired the committee. The other members were C L D Meares, a Judge of the New South Wales Supreme Court, and P S Atiyah, an English academic who had taken up an appointment as a professor of law at the Australian National University and who was the author of a well-known book, Accidents, Compensation and the Law, ${ }^{15}$ which was first published in 1970 and which was highly critical of the common-law tort system. For personal reasons, Professor Atiyah resigned from the committee and returned to England. He was not replaced.

The principal assistant to the committee was Geoffrey Palmer, then a New Zealand professor of law. While teaching at the University of Iowa, he had been retained by the New Zealand Government to draft the White Paper ${ }^{16}$ that was issued after the report of the New Zealand Royal Commission $^{17}$ that Woodhouse had chaired. Later, of course, he became Prime Minister of New Zealand.

Woodhouse wanted the report of the inquiry not to be misunderstood, as he believed the New Zealand Royal Commission's had been. To obviate such misunderstanding, he intended to attach to the report a draft bill. For this purpose, Mr J Q Ewens, who had recently retired after many years as First Parliamentary Counsel, was appointed as an assistant to the committee. Not only did he bring to the committee great knowledge and skill, but he became an enthusiastic supporter of the proposed scheme.

\section{A Original Terms of Reference}

The terms of reference originally given to the committee announced that the Government had in principle decided to establish a National Rehabilitation and Compensation Scheme. ${ }^{18}$ Two points

12 Whitlam memoir, above.

13 Palmer, above, 133.

14 Whitlam memoir, above, 637.

15 Patrick S Atiyah Accidents, Compensation and the Law (Weidenfeld \& Nicolson, London, 1970).

16 New Zealand Department of Labour Personal Injury: A Commentary on the Report of the Royal Commission of Inquiry into Compensation for Personal Injury in New Zealand [1969] IV AJHR H 50.

17 New Zealand Royal Commission of Inquiry into Compensation for Personal Injury Compensation for Personal Injury in New Zealand: Report of the Royal Commission of Inquiry (Government Printer, Wellington, 1967).

18 Australian National Rehabilitation and Compensation Committee of Inquiry Compensation and Rehabilitation in Australia: Report of the National Committee of Inquiry (Australian Government Publishing Service, Canberra, 1974). The Chairman of this Committee was A Owen Woodhouse. 
are particularly worth noting about this announcement. First, rehabilitation was placed before compensation. The committee itself stated that the problem of incapacity demanded an attack on three fronts: ${ }^{19}$

The most important is obviously prevention. Next in importance is the obligation to rehabilitate the injured and the sick. Finally, there is the need to provide financial assistance in the form of compensation for their losses. The priorities need to be emphasised and particularly it is necessary to ensure that the objective of compensation does not bear down upon the far more important need for the restoration of health and physical well-being.

The second point is that these terms of reference were not aimed at establishing whether there should be a national rehabilitation and compensation scheme. They accepted that the Government had already made a decision to establish such a scheme. The purpose of the scheme was to compensate every person who at any time suffered personal injury, including pre-natal injury, whether on the road, at work, at home, at school or elsewhere. The committee's function was to inquire into and report on the scope and form and manner of instituting and administering the scheme. The terms of reference set out various more particular matters for the committee's consideration, such as the coverage of the scheme, its benefits and financing.

\section{B Extension to Sickness}

Almost a year after its appointment, on 1 February 1974, the committee's terms of reference were extended. It was directed to inquire also into whether and how the scheme should cover the rehabilitation and compensation of every person who suffers physical or mental incapacity or deformity by reason of sickness or congenital defect. This was to include death resulting from such sickness or defect. ${ }^{20}$ In contrast to the original terms of reference relating to injury, there was no statement of commitment in principle by the Government to introduce such an enlarged scheme. Palmer castigates the manner of extending the terms of reference as unfortunate, at time when many submissions to the committee had already addressed the original ones. ${ }^{21}$

\section{Report}

The committee reported to the Prime Minister on 27 June 1974, fifteen months after its establishment. Its report was published in three volumes. Whitlam described it as "one of the most convincing and stimulating reports ever presented to the Parliament". ${ }^{22}$ It did recommend the extension of the scheme to incapacity due to sickness and congenital defect. There were, however,

19 Compensation and Rehabilitation in Australia, above, para 8.

20 Compensation and Rehabilitation in Australia, above, para 23.

21 Geoffrey Palmer Compensation for Incapacity: A Study of Law and Social Change in New Zealand and Australia (Oxford University Press, Wellington 1979) 135.

22 E Gough Whitlam The Whitlam Government 1972-1975 (Penguin Books, Melbourne, 1985) 639. 
some qualifications. For instance, for reasons advanced in the report, there was to be a longer waiting period before payment of compensation commenced in the case of a person incapacitated by sickness (three weeks) than in the case of a person who suffered personal injury (one week). ${ }^{23}$

Basically, the committee recommended an earnings-related compensation scheme. ${ }^{24}$ Compensation was to be paid by means of weekly payments at a rate of 85 per cent of lost pre-tax average earnings. A notional income, based on general average weekly earnings, was to be ascribed to non-earners. There were provisions for estimating the earnings of juniors, with a reassessment at certain ages. Hospital, medical and rehabilitative expenses, it was envisaged, would be paid under the Government's separate proposals to establish a universal health scheme, though it would be necessary to make "appropriate provision" if those proposals were not implemented. ${ }^{25}$

In Appendix 1 of his book, ${ }^{26}$ Palmer lists changes that were made in 36 policy areas as the proposals for a comprehensive compensation scheme proceeded through four stages each in New Zealand and Australia. The first stage in New Zealand was the report of the Royal Commission and the fourth was the Accident Compensation Act 1972 after its initial amendments. ${ }^{27}$ The first stage in Australia was the report of the Woodhouse Committee. ${ }^{28}$ Key differences between the respective first stages included -

- In New Zealand the scheme was confined to personal injury by accident; in Australia it encompassed all incapacity, irrespective of cause.

- In New Zealand, the benefits for total incapacity were based on $80 \%$ of post-tax earnings and were not themselves taxed; in Australia, they were based on $85 \%$ of pre-tax earnings and were subject to income tax.

- The Australian proposals ascribed a relatively generous notional earnings rate to nonearners.

- The Australian proposals refined the method of assessing permanent partial incapacity. They introduced the American Medical Association's Guides to the Evaluation of Permanent Impairment and also made provision for a lump-sum payment for cosmetic

23 Compensation and Rehabilitation in Australia, above, para 377.

24 See the Committee's own summary, Compensation and Rehabilitation in Australia, above, para 343.

25 Compensation and Rehabilitation in Australia, above, para 372.

26 Geoffrey Palmer Compensation for Incapacity: A Study of Law and Social Change in New Zealand and Australia (Oxford University Press, Wellington, 1979).

27 New Zealand Royal Commission of Inquiry into Compensation for Personal Injury Compensation for Personal Injury in New Zealand: Report of the Royal Commission of Inquiry (Government Printing Office, Wellington, 1967).

28 Compensation and Rehabilitation in Australia, above. 
injury. The Guides have since been widely used in Australian compensation schemes for motor and industrial accidents, but have also been much criticised. ${ }^{29}$

- The Australian scheme made provision for payment of a benefit in the case of temporary partial incapacity.

- The Australian proposals recognised that the need for a personal attendant and domiciliary care would arise in some cases and that it should be met under the scheme. A comprehensive plan for rehabilitation services was advanced.

- The Australian scheme provided for indexation of benefits at much more frequent intervals and by reference to more appropriate measures than in New Zealand. Indexation would also include an allowance for productivity gains.

- $\quad$ Suicide and self-inflicted injuries would not have been excluded in Australia.

\section{Public Reaction to the Report}

The report of the committee received relatively little publicity. Journalists and others seemed not really to understand the proposals and how radical they were in the context of existing remedies. Newspapers tended to push the issue to the back pages. They seemed much more interested in reports relating to financial losses suffered by the greedy than the needs of the victims of injury and sickness. One reason might have been a surfeit of inquiries and reports. Palmer states that by November 1973 the Whitlam Government had set up 94 commissions or committees of inquiry. ${ }^{30}$

\section{E Administrative Problems}

Many of the inquiries overlapped with each other and some impinged on the Woodhouse terms of reference. However, there was little co-ordination among them. Responsibility for the implementation of the Woodhouse report shifted from department to department and minister to minister. ${ }^{31}$ This was not conducive to overcoming the opposition the proposed scheme provoked.

\section{F Lack of Support from Natural Allies ${ }^{32}$}

It was necessary that the scheme replace existing remedies for personal injury. In Australia, there is a workers' compensation scheme in each State and Territory, as well as one for Commonwealth employees, and some specific schemes, like those for dust diseases in New South

29 See, for example, Patrick Mulvany and N Horner "The Use and Abuse of the American Association Guides in Accident Compensation Schemes" (1998) 6 JLM 136.

30 Geoffrey Palmer Compensation for Incapacity: A Study of Law and Social Change in New Zealand and Australia (Oxford University Press, Wellington, 1979) 141.

31 Palmer, above, 140-158.

32 On this and the next section, see generally Palmer, above, Ch XII "The Pressure Groups in Australia". 
Wales and for seafarers. In four States workers had won the right to 100 per cent earnings replacement for varying periods. The Commonwealth scheme's benefits had fallen well behind those of the States and the Government moved swiftly to make them comparable. In a new Commmonwealth employees' compensation Bill, it made similar provision for benefits at a level of 100 per cent of earnings. The unions subsequently opposed any reduction in these benefits. They refused to accept a trade-off of a lesser percentage for 24-hour, seven-day coverage. "What we have, we hold" was their catchcry.

This was a recurrent theme. Many who could be expected to support the Woodhouse scheme said that they were not opposed to it, or even did offer qualified support for a national compensation scheme, but they insisted that none of their members should be worse off under the new scheme than under whatever old scheme they operated under.

Welfare lobbyists, too, were puzzled as to how to respond. They were used to Australia's system of social security with contributions based on supposedly progressive income taxes and stringently means-tested flat-rate benefits. Funds raised from levies on petrol, as one source contemplated by the Woodhouse committee, in order to pay earnings-related benefits up to a very high level of earnings simply did not fit into the general pattern and involved a redistribution of wealth in the wrong direction. One noted welfare economist, Professor Richard Downing, commented that he personally would be willing to pay high contributions for earnings-related benefits in the event of injury or sickness and also on retirement (a possible outcome of an inquiry into superannuation, which was also on foot), but his "assessment of human nature" led him "to favour ... means-tested benefits plus generous encouragement of and support for self-reliance". ${ }^{33}$

\section{G Organisations Opposed}

More expectably, opposition came from particular interest groups who stood to lose under the new scheme. The organisations representing lawyers led the objectors, with claims that "rights" would be eroded and benefits would fail to match the full compensation they claimed the common law provided. They contested the studies undertaken by the committee that demonstrated that periodical benefits payable for the whole period of incapacity would easily match the real value of lump sums that failed accurately to predict the future and were eroded by inflation. They also ignored the fact that certainty of recovery of a reduced benefit was in real terms worth much more than the chance of recovering a higher sum that might theoretically have been available on successful proof of fault, but which was actually available only to a small proportion of claimants. They were not moved by anecdotal evidence such as the poignant letter from the mother of a young

33 Richard I Downing "Social Reconstruction, Social Welfare and Self-Reliance" (George Judah Cohen Memorial Lecture 1974, Sydney, 1975) 19. 
woman who had recovered record damages from the New South Wales Supreme Court, only to find that the whole amount was insufficient to pay for her nursing care 10 years later. ${ }^{34}$

Not only had the legal profession seen what had happened in New Zealand and perceived the danger to the livelihood of many of them, and so were apparently better prepared and organised, but they were more united and less public-spirited than their counterparts in New Zealand. Whitlam refers to labour lawyers having "collaborated in the campaign" against the scheme; those who specialised in work for unions having "aided and abetted" the opposition, because "the basis of their thriving practices [was] to charge unions for their expert advice in cases of accidents at work or on the way to and from work". ${ }^{35}$

Similarly, the official organisations representing doctors seem to have been captured by those of their members who made a lucrative income from medico-legal reports. Traditionally, too, doctors who treated people injured in circumstances where compensation was available were able to charge higher fees than they charged their other patients. They feared that a government monopoly administering a comprehensive compensation scheme would control their fees at a lower level. Few saw the writing on the wall that the medical profession itself would become a prime target of litigation and subjected to an alleged medical indemnity crisis in the next millennium, which could be avoided by the immunity from suit that the proposed scheme offered. Even today, many representatives of the profession have a naïve belief in the worth of the fault system in maintaining standards and supposedly eliminating the few "bad apples" among practitioners. They fail to recognise that the medical indemnity system ensures that claims against those who are truly negligent are quickly settled on a confidential basis without any publicity; while practitioners whose negligence is borderline are exposed to adverse publicity as a result of open hearings in court under newspaper scrutiny.

The insurance industry stood to lose most. As a result of the Government's original commitment to an accident compensation scheme, general insurers would have been deprived of their cash flows and their access to clients who would also take out insurance of a more profitable nature than employers' liability insurance or third party motor vehicle insurance. Once the terms of reference were expanded, life insurers, who offered disability and similar insurance, saw themselves as threatened. At the same time, insurers were fighting another proposal - to create an Australian Government insurer that would compete against them in the same way as at the time the

34 See the letter from Mrs E O Martin in National Rehabilitation and Compensation Committee of Inquiry Compensation and Rehabilitation in Australia: Report of the National Committee of Inquiry (Australian Government Publishing Service, Canberra, 1974) vol 1 appendix 6. Her daughter was the plaintiff in Thurston v Todd [1965] NSWR 1158; [1966] 1 NSWR 321 (CA).

35 E Gough Whitlam The Whitlam Government 1972-1975 (Penguin, Melbourne, 1985) 640 (Whitlam memoir). 
Commonwealth Bank competed against the private banks. Their opposition was fierce, and extended to encouraging their employees to march against an alleged threat to their jobs.

As always in Australia, there were those who advocate States' rights and resist each attempt by the central government to take away what they see as their traditional responsibilities. Accident compensation had always been a matter for the States and the proposed scheme amounted to a Commonwealth takeover.

\section{CONSTITUTIONAL PROBLEMS}

This brings us to the major difference between Australia and New Zealand. Australia is a federation, not a unitary state. The Commonwealth Parliament is bicameral. Each of these factors played a significant role in the failure to implement the Woodhouse scheme.

The Constitution gives a list of powers to the Commonwealth Parliament; residuary power rests with the States. There was considerable doubt as to the power of the federal Parliament to enact a law which provided for the payment of all the necessary benefits under the scheme. Furthermore, there was grave doubt that any of the existing heads of power would support the abolition of all common-law rights, which was crucial to the success of the scheme. The Woodhouse Committee relied heavily on advice from the Solicitor-General, Mr M H Byers, that with certain changes, which could be accommodated, the proposed legislation would withstand the inevitable challenge in the High Court of Australia. Mr Ewens' experience was also helpful in this regard. Ranged against these views were formal opinions of three people, described by Whitlam as "charlatans", ${ }^{36}$ who were then leading QCs, two of whom subsequently became chief justices of Australia and the third of whom became a Supreme Court Judge and State governor.

The other problem was that the Government did not have a majority in the upper house of the federal Parliament, the Senate. After the Bill to implement the scheme had been passed in the House of Representatives, the Senate referred it to its Constitutional and Legal Affairs Committee, where it stalled for many months.

\section{THE SENATE COMMITTEE}

The Senate Committee was evenly divided, with three Government and three Opposition members. After long hearings and consideration of many submissions, it was able to reach unanimity on many issues. It recognised the flaws in the existing system of accident compensation. With some prescience, it stated: ${ }^{37}$

The committee is attracted to many of the principles and aims of the Bill. It is clear that the compensation systems are random in their coverage, often provide inadequate compensation and can

36 Whitlam memoir, above.

37 Senate Standing Committee on Constitutional and Legal Affairs Report on the Clauses of the National Compensation Bill (Australian Government Publishing Service, Canberra, 1975) paras 1.21-1.22. 
give rise to inequities. The committee is concerned that existing social service benefits for sickness are inadequate and that compensation for injuries is effectively limited to work-caused injuries suffered by employees, to some victims of criminal acts and to those victims of highway accidents who can establish fault in other persons and are not disqualified by want of care on their part. The committee believes that recent attempts - for example, in Victoria and Tasmania — to reform the existing systems remain too limited in their scope ...

The committee believes that unless significant changes are made to existing remedies for injury, most of which are financed by insurance, their cost will become too high to be financed by insurance premiums and governments will be required to provide supplementary financial assistance. It seems logical to the committee that, if governments are to be required to give financial assistance in this area, it is an appropriate time to consider new approaches to the provision of more equitable and comprehensive coverage at the lowest possible cost ...

Nevertheless, it saw "significant deficiencies in the provisions of the Bill". It had "serious doubts as to the constitutional validity of the Bill". In the end, it recommended that the "Bill be withdrawn and reconsidered in accordance with the unanimous or majority recommendations of the committee". 38

\section{BILL REDRAFTED}

The Bill was withdrawn and redrafted. In accordance with a recommendation of the Senate Committee, it was confined to injury. It was ready to be introduced in November 1975, when the Whitlam Government was dismissed by the Governor-General after supply had been held up in the Senate. Whitlam lost the subsequent election. As a private member, he personally introduced the redrafted Bill on 24 February 1977. The Fraser Government of the day did not allow it even to go to a vote. ${ }^{39}$ Whitlam has since described the failure to institute a national rehabilitation and compensation scheme as "[o]ne of the great disappointments of my life". ${ }^{40}$

\section{SUBSEQUENT EVENTS}

The incoming Liberal Coalition Government did not directly kill the proposals. There was talk at the time of achieving its ends through "co-operative Federalism", namely between the State and Federal governments. But without the impetus of a strong supporter in the Government, it simply died away. The Northern Territory, under conservative governments, did implement a no-fault motor scheme for Territory residents that eventually denied any common law actions and a workers'

\footnotetext{
38 Senate Standing Committee on Constitutional and Legal Affairs, above, para 1.23.

39 Whitlam memoir, above, 641.

40 Whitlam memoir, above, 635.
} 
compensation scheme that similarly denied common law actions, ${ }^{41}$ but these initiatives did not spread.

\section{LABOR PROPOSALS}

A Labor Government was again elected in 1983. Its platform included an "ultimate objective" of a "nationwide scheme which ensures speedy compensation at reasonable levels for all persons injured in any kind of accident". It envisaged that this objective would be attained in a series of steps taken at State and Federal level:

(1) first, there would be a uniform no-fault motor accident scheme;

(2) then, workers' compensation would be extended to cover workers 24 hours per day, seven days per week, instead of only at work and on certain journeys to and from work;

(3) thereafter, the benefits under the uniform no-fault motor accident scheme and under workers' compensation would be rationalised; and

(4) finally, there would be a Commonwealth scheme for those not covered by these State schemes.

\section{A Non-implementation of these Proposals}

Although there were Labor Governments in office federally from 1983-96, they did little to implement these proposals. In New South Wales, however, the Law Reform Commission had meanwhile been given a reference on transport accidents. In 1984, it put forward a detailed no-fault scheme. ${ }^{42}$ However, it was never implemented by the many successive Labor (and other) governments in that State. Some of its recommendations were (ill-)adapted to an administrative fault-based transport accident scheme, which was retrospectively repealed two years later. ${ }^{43}$ There is evidence that only approximately $40 \%$ of catastrophically injured motor accident victims in New South Wales receive compensation and that the cost of providing no-fault benefits to those who become quadriplegic, paraplegic or severely brain-injured and who presently receive nothing under the fault system would only add $\$ 37$ to the average motorist's premium of over $\$ 400$. Yet seeing this as the thin edge of the wedge to a complete no-fault scheme caused some New South Wales Parliamentarians to react with horror against the idea of providing such compensation. ${ }^{44}$

41 Motor Accidents (Compensation) Act 1979 (NT); Work Health Act 1986 (NT).

42 See its two-volume report: New South Wales Law Reform Commission Report on a Transport Accidents Scheme for New South Wales (LRC 43, Sydney, 1984).

43 See the Transport Accidents Compensation Act 1987 (NSW), repealed by the Motor Accidents Act 1988 (NSW), s 5 .

44 See the debate on the Second Reading of the Motor Accidents Compensation Bill 1999 (NSW): (22 June 1999) Hansard 52 Parliament Leg Council <http://www.parliament.nsw.gov.au/ prod/web/PHWeb.nsf/Hansard?OpenFrameSet>. 


\section{B Partial Implementation in Victoria}

In Victoria, however, the Cain Labor Government introduced a no-fault transport accident scheme based on the New South Wales Law Reform Commission's model from 1 January $1987 .{ }^{45}$ A lack of a majority in the upper house led the Government to compromise and to retain a commonlaw right of action for a "serious injury" as defined in the legislation. There has since been some rationalisation between the benefits under this scheme and workers' compensation, but the latter has not been extended to 24-hour cover. Indeed, the conservative Kennett Government removed the cover for journeys to and from work and required that employment make a "significant" contribution to any injury before it was compensated. ${ }^{46}$

Abolition of common law actions in workers' compensation has been a political football kicked from side to side by successive governments in Victoria, the Labor and Liberal parties having changed sides several times on this issue. Such actions were abolished almost completely by the last Liberal Government, but were reintroduced by the present Labor Government, though only for "serious injury", which is defined in a similar way to the definition in the transport accident legislation.

\section{TODAY}

Late in 2002, there are Labor governments in every State and self-governing Territory of Australia. But there have been no moves to introduce a Woodhouse-type scheme anywhere. Throughout the year there has been a debate raging about the huge increases in public liability premiums that have been foisted on small business and non-profit organisations, mainly as the result of the collapse of a large insurance group, HIH, which had aggressively sought market-share and previously cut its premiums, apparently unsustainably. ${ }^{47}$ At the same time, a medical indemnity fund has also become unable to meet its obligations and the Federal Government, in order to keep doctors working, has come to its aid with huge subsidies. ${ }^{48}$

In this context, in January 2002, the Federal Minister for Small Business suggested that the New Zealand scheme be investigated to see whether it should be adopted in Australia. He was immediately howled down by representatives of lawyers and others and told to keep to his portfolio by more senior ministers. ${ }^{49}$ Instead, the State and Federal Governments jointly set up a committee

45 Transport Accident Act 1986 (Vic).

46 Accident Compensation Act 1985 (Vic), as amended.

47 The collapse of HIH is the subject of a Royal Commission that has been investigating it for many months.

48 See, for example, Darren Gray and Tom Noble "Camberra Pledges Insurance Crisis Aid" (1 May 2002) The Age Melbourne 3; John Kerin and Andrew White "Medical Rescue Operation" The Australian (1 May 2002).

49 See, for example, S Kemp and A Crabb "Compensation Scheme Comes under Fire" (22 January 2002) The Age Melbourne; AAP "Lawyers Call for Meeting with Hockey over Compo Scheme" (23 January 2002) 
of "eminent persons" to conduct a "principles-based" review of the law of negligence. ${ }^{50}$ Without waiting for the report of that committee, all the States have moved to tighten liability for negligence and to limit damages. ${ }^{51}$ But retention of the common law seems sacrosanct. The emphasis in many of these "reforms" is increased "personal responsibility". No longer does the Woodhouse call for "community responsibility" resonate among politicians and the public.

Australian Current Law News; Josh Gordon "Hockey Shunts Public Liability to the States" (15 February 2002) The Age Melbourne 7.

50 See Commonwealth of Australia Final Report of the Review of the Law of Negligence (Australian Government Publishing Service, Canberra, 2002) (the "Ipp report").

51 CCH News Headlines "Where Are We Now?" 2002 (3 October 2002); CCH News Headlines "Where Are We Now, New South Wales?" (4 October 2002); CCH News Headlines, "Where Are We Now, Victoria?" (8 October 2002); CCH News Headlines "Where Are We Now, South Australia?" (10 October 2002); CCH News Headlines "Where Are We Now, Western Australia?" (11 October 2002); CCH News Headlines, "Where Are We Now, Tasmania?" (14 October 2002); CCH News Headlines "Where Are We Now, Northern Territory?" (15 October 2002); CCH News Headlines "Where Are We Now, ACT?" (16 October 2002); CCH News Headlines "Tort Legislation Keeps on Coming" (24 October 2002). 